\title{
Incidentalomas: concept, relevance and challenges for medical practice
}

\author{
Incidentalomas: conceito, relevância e desafios para a prática médica \\ Incidentalomas: concepto, relevancia y retos para la práctica médica
}

María Ana Mariño. Sociedad Argentina de Medicina Interna General (SAMIG). Ciudad de Buenos Aires, Argentina. marian_marino@yahoo.com.ar (Corresponding author)

\section{Abstract}

Incidentaloma (which has not been included as a MeSH term neither in other medical databases or Bioportal) is a neologism used to describe an incidentally discovered mass (or abnormality) in asymptomatic persons. Incidentaloma, or incidental finding, is extremely common now and in most cases harmless, but sometimes it is not possible to exclude the possibility of real damage and in very few cases, some people can get benefit from its discovery. Therefore, most of incidentalomas represent overdiagnosis originated by the massive use of high-resolution diagnostic procedures. In many cases, incidentaloma causes anxiety, consume time and resources, and can even cause further damage to patients' health as a result of procedures performed in the post-finding follow-up. Thus, it is important to recognize the problem to try to avoid it if possible, and learn strategies to deal with it once we stumbled upon an incidentaloma.

\section{Resumo}

0 incidentaloma (ainda não incluído como um termo MeSH, nem em outros bancos de dados biomédicos ou 'BioPortais') é um neologismo utilizado para descrever uma massa (ou anormalidade) descoberta de modo incidental em pessoas assintomáticas. Os incidentalomas, ou achados incidentais, são extremamente comuns nos dias de hoje, e na maioria dos casos, inofensivos, mas por vezes não se pode excluir a possibilidade real de dano, $e$ em raríssimos casos, algumas pessoas podem se beneficiar devido à sua descoberta. Isso ocorre porque a maioria dos incidentalomas representa sobrediagnóstico causado pelo uso massivo de métodos de diagnóstico de alta-resolução. Em muitos casos, o incidentaloma causa ansiedade, consome tempo e recursos, e pode até causar maiores danos para a saúde dos pacientes, como resultado dos procedimentos realizados no seguimento posterior ao achado. Sendo assim, é importante reconhecer o problema para se tentar evitá-lo tanto quanto possível, e aprender estratégias para lidar com situações onde nos deparamos com incidentalomas.

\section{Resumen}

El incidentaloma (que no ha sido incluido como un término MeSH, ni tampoco en otras bases de datos biomédicas o 'Bioportales') es un neologismo usado para describir una masa (0 anormalidad) descubierta en forma incidental en personas asintomáticas. Los incidentalomas, o hallazgos incidentales, son extremadamente comunes actualmente, y en la mayoría de los casos son inofensivos, pero algunas veces no se puede excluir la posibilidad real de daño, y en muy pocos casos algunas personas se beneficiarán debido a su descubrimiento. Esto se debe a que la mayoría de los incidentalomas representa sobrediagnóstico originado por el uso masivo de métodos diagnósticos de alta resolución. En muchos casos, el incidentaloma causa ansiedad, consume tiempo y recursos, e incluso puede causar un mayor daño a la salud de los pacientes como consecuencia de los procedimientos realizados en el seguimiento posterior al hallazgo. Resulta importante reconocer el problema, para tratar de evitarlo en cuanto sea posible, y aprender estrategias para lidiar con situaciones donde nos encontramos con incidentalomas.

\section{Keywords:} Incidentaloma Incidental Findings Medicalization Quaternary Prevention

Palavras-chave: Incidentaloma Achados Incidentais Medicalização Prevenção Quaternária

Palabras clave: Incidentaloma Hallazgos Incidentales Medicalización Prevención Cuaternaria 


\section{Introduction}

Incidental findings in diagnostic procedures are actually an increasing problem derived from the massive use of medical technology. The increased availability of sophisticated high-resolution tests has uncovered too often finds or "abnormalities" that in the past remained hidden. Many people (symptomatic or not) are subject to increasingly numerous procedures, including CT (computed tomography) and MRI (magnetic resonance imaging) which often visualizes much more than the area of interest. This is the origin of incidental findings or "incidentalomas": the unexpected results of a workup made for another purposes. This narrative review will try to explain briefly the concept of incidentaloma and some examples different from adrenal incidentaloma, the magnitude of the problem we face once it is discovered, and different visions about how to cope with it.

"Incidentaloma" is not a MeSH term. It is included in the compound term "Adrenal incidentaloma", a supplementary concept introduced in 2010. The equivalent MeSH term is "Incidental findings". ${ }^{1}$ It is also not included in another medical databases or Bioportal (DeCS, Hetop, Woncadic); but it appears in other non-specialized sites (like BabelNet or Wikipedia) where it is defined as a tumor found by coincidence without clinical symptoms or suspicion. ${ }^{2}$ Incidentaloma is a neologism that describes a totally asymptomatic mass or lesion that is discovered "incidentally" in an asymptomatic patient due to the common use of diagnostic imaging techniques. ${ }^{3}$ First, this term was introduced to describe an adrenal mass incidentally found ${ }^{4-7}$ but later on, it has also appeared in the literature in reference to other endocrine organs, ${ }^{8-12}$ or in organs such as liver, ${ }^{13}$ kidney, ${ }^{14}$ and brain. ${ }^{15}$ The concept does not imply etiology neither prognosis of the findings, because they may be benign or malignant lesions, hormonally active or inactive, metastases, infections, granulomas, infiltrations, cysts and pseudocysts, hemorrhages, etc. ${ }^{3}$ These findings fall outside the primary purpose for conducting a test or procedure used in clinical care (as a screening or diagnostic test) or research, and may be anticipated (known to be potentially associated with the test) or unanticipated (not typically associated with the procedure). ${ }^{16-18}$

\section{The burden of the problem}

Human beings have a lot of reservoirs of incidentalomas, and most of them are subclinical indolent malignancies besides minor benign abnormalities. ${ }^{19-22}$ It is more probably to find an incidentaloma than the searched diagnosis, as shown in one study of CT angiography for pulmonary embolism where incidental findings requiring follow-up were nearly three times more common than emboli. ${ }^{23,24}$ Incidental findings have changed disease incidence, ${ }^{24}$ for instance, thyroid cancer incidence has increased more than doubled over 30 years because of the increasing use of thyroid ultrasound and the high rate of incidental nodules, ${ }^{25}$ (later discussed in this paper); there has also been a $61 \%$ increased incidence of renal cell carcinomas attributed to their incidental detection on CT scans performed for other reasons. ${ }^{24}$

Small lung nodules are the most common incidentaloma as they are detected on chest TC in roughly 15 percent of nonsmokers and in up to 50 percent of smokers. Of every ten thousand CT scans, at least a thousand will have an incidentaloma, but less than five will progress to overt cancer. ${ }^{26,27}$ Unexpected findings can be found by cancer screening (for example, screening for colon cancer with CT - colonography or "virtual" colonoscopy - detects extra-colonic abnormalities in up to $50 \%$ of examinations, and the detection rate of unsuspected extra-colonic cancer is approximately one per 200 asymptomatic adults); ${ }^{28-32}$ but interventions unrelated to screening can also lead to early cancer detection. ${ }^{19}$ Diagnostic scanning of the abdomen, pelvis, chest, head, and neck can reveal incidentalomas in 25 to up to $80 \%$ of individuals being tested for other reasons. ${ }^{33,34}$ In the $86 \%$ of the radiologic reports of 1.192 consecutive patients who underwent whole-body CT screening of the chest, abdomen, and pelvis at an outpatient imaging center, incidental findings were discovered. Thirty seven percent of patients received at least one recommendation for further evaluation. Only in $14 \%$ scans were completely negative for any findings. ${ }^{33}$ The frequency of incidentalomas for any test in a review of 44 studies ( 41,866 patients) was $23.6 \%$ (95\% confidence interval [CI] 15.8-31.3\%), was higher in studies involving CT technology (mean 31.1\%, 95\% CI 20.1-41.9\%), in patients with an unspecific initial diagnosis (mean 30.5\%, 95\% CI 0-81.6\%) and when the location of the incidental findings was unspecified (mean 33.9\%, 95\% CI 18.1-49.7\%). Sixty four percent of incidental findings had clinical follow-up (95\% CI 52.9-76.1\%) and the mean frequency of clinical confirmation was $45.6 \%$ (95\% CI 32.1-59.2\%). ${ }^{34}$ 
Brain incidentalomas have become very frequent and problematic due to the increased use of MRI of the brain by physicians (in clinical situations where the prevalence of any relevant finding is likely to be low), researchers and companies that sell health "check-ups". In a meta-analysis of 19,559 apparently healthy participants (healthy people, volunteers, research controls, and people undergoing commercial, clinical, or occupational screening), the global prevalence of incidental findings on brain MRI, was $2.7 \%$ with a number needed to scan $=37$ (it means, for every 37 scans there is one incidental finding), $0.7 \%$ for neoplastic findings and $2 \%$ for non-neoplastic findings. The more common neoplastic finding was meningioma, and the non-neoplastic findings were arachnoid cyst and aneurysms in second place. ${ }^{15,35}$

Detection is potentially detrimental because the treatment can be harmful, as well as the complication it tries to prevent. For instance, the risk of rupture of a non-complicated aneurysm seems to be low: an average annual incidence of 1.1\% (in a study with a median follow-up time was 21.0 years - range: 0.8 - 52.3 years - of 142 patients with 181 unruptured intracranial aneurysms $\mathrm{s}^{36}$ ) to $1.4 \% \cdot{ }^{37}$ But the risk associated with the treatment is higher: procedure-related poor outcomes occurred in $4.7 \%$ of patients in a review of endovascular treatment of intracranial unruptured aneurysms, with $1.4 \%$ of deaths per year. ${ }^{38}$ In most of intracranial vascular incidentalomas, the 5-year risk of complications is higher in treated patients than in untreated persons. ${ }^{39}$ So, people probably would be better off not hearing that they had a potentially serious condition for which treatment is more likely to damage than the vascular incidentaloma left to its natural evolution.

A task force of the Stroke Council of the American Heart Association (USA) published recommendations for the management of patients with an unruptured intracranial aneurysm. They said that given the apparent low risk of hemorrhage from incidental, small $(<7 \mathrm{~mm})$ aneurysms in patients without previous subarachnoid hemorrhages, observation rather than intervention is generally suggested; however, special consideration for treatment should be given to patients $<50$ years in this group. In the case of asymptomatic aneurysms $\geq 7$ to $10 \mathrm{~mm}$ in diameter warrant strong consideration for treatment, taking into account patient age, existing medical and neurologic conditions, and relative risks for treatment. ${ }^{40}$

Suppose a person who faces an aneurysm chooses to undergo the surgical treatment. Complete reassurance for this person is not even possible after treatment, because further aneurysms may yet develop. Therefore, patients must repeat the screening (whose optimum interval and duration remain unknown), situation that can cause stress and anxiety, and prior to which an aneurysmal subarachnoid hemorrhage might still occur. Even if a further aneurysm is identified by follow-up angiography, it might be too small to be treatable, and this knowledge is likely to impair quality of life. ${ }^{15}$

The massive use of image studies of the pelvis has led to the detection of incidental ovarian, uterine, vascular and pelvic nodal abnormalities in the oncology and non-oncology patient population that in the past remained undiscovered. In a retrospective review of 3,448 CT scans performed in both pre- and postmenopausal women, incidental adnexal lesions were found in 168 patients (5\% of cases), 72 of which had extra-ovarian neoplasms. In both pre- and postmenopausal women, these lesions most often proved to be benign, even in the presence of a known malignancy (excluding ovarian carcinoma). In the $40 \%$ of patients with known non-gynecologic malignancies, no primary ovarian neoplasms were discovered, and only three percent of the lesions represented metastases, all of which were found in postmenopausal women. No primary ovarian malignancies were discovered incidentally in the non-oncology population either. ${ }^{41}$

The risk of malignancy in a premenopausal woman with an indeterminate ovarian mass is approximately $8.75 \%$; in postmenopausal women, this risk increases to $32.4 \%$. There are findings that suggest malignancy: size, solid mass, necrosis, involvement of adjacent organs or the pelvic side walls; etc. ${ }^{42}$ Unilocular, benign-appearing ovarian cysts represent the vast majority of abnormal findings at transvaginal ultrasonography. Eighty percent of the incidentalomas will disappear in several months; ${ }^{43}$ but the problem is that, even in cases of suspected malignancy image, finding and treating ovarian cancer in asymptomatic women has proven to be not only useless but dangerous. In the PLCO trial (Prostate, lung, colon and ovarian cancer screening trial), simultaneous screening with CA-125 and transvaginal ultrasound did not reduce ovarian cancer mortality. Approximately $10 \%$ of screened women suffered false positive results; a third of whom underwent surgical follow-up; and $15 \%$ of that women experienced at least one serious complication. ${ }^{44}$

Despite in this case there is not a visible lesion, incidental findings in genetic or genomic examinations have been also called incidentalomas (genomic or genetic incidentalomas). ${ }^{45} \mathrm{~A}$ broader definition of genomic incidental findings includes health-informative variants that are unrelated to the specific purposes of testing, but may have been identified through an intentional search, including an untargeted scan for any genetic finding of interest. ${ }^{17}$ The broad array of genome-scale screening tests (increasingly prevalent in clinical and research) may lead to a phenomenon in which multiple abnormal genomic findings are discovered, analogous to the radiologic incidentalomas. ${ }^{45}$ 
Genetics incidentalomas can be identified by any genetic test; however, they are likely to be increasingly identified from genome sequencing methods such as whole genome sequencing or whole exome sequencing. As in others incidentalomas, genomic incidental findings are classified according to their likely pathogenicity, but each laboratory has its own policies for identifying, analyzing, and reporting incidental findings. Also, each laboratory decides what risk assessment to assign to each variant within the gene; this is generally done according to an accepted classification scheme based on the likely clinical significance of each variant. However, laboratory assessments regarding the significance of a variant may diverge when the pathogenicity of the variant has not been established previously. ${ }^{46}$ Again, one controversial area involves the handling of the medical information found through genomic sequencing.

The American College of Medical Genetics and Genomics has identified a list of genes associated with 24 conditions that it considers a minimal set for which known or likely pathogenic variants should be reported, that usually consider the existence of validated screening procedures to confirm the presence or absence of disease. ${ }^{47}$ But, genetic is not destiny. In this case, we incidentally find not even a risk factor, let alone an early disease. We have to deal with the risk to develop a risk factor or a disease.

The risk of disease is also influenced by the disease penetrance and expressivity, which varies by patient population. Few genetic abnormalities have penetrance of $100 \%$ (that is the measure of how well the genotype predicts phenotype). There may be relatively broad consensus in reporting a known pathogenic variant in a known cancer gene (e.g. pathogenic BRCA1 mutation). But even the BRCA 1 and 2 have an estimated penetrance from $30 \%$ to $70 \%$, and this is the possibility of develop breast cancer by age seventy, not dying from it. Virtually, everybody has genetic abnormalities despite the most have normal phenotype. ${ }^{27}$ Between 25 and 50 percent of individuals are carriers for at least one severe, recessive childhood disorder, although estimates as high as 2.8 carrier variants per person have been noted. ${ }^{46}$ Many times there are incomplete and changing knowledge of the specific effects of single variants, and of clinically relevant genomic biology in general; and some genomic variants predict a strong chance of disease at some point in the future, but there may be no clinical signs of the disease at the time of detection meaning that we have no way to exclude or confirm the diagnosis, thus we add more doubts and concerns than certainties. ${ }^{48}$

In summary, the word incidentaloma implies the discovery by chance of some lesion that probably never will harm the person, ${ }^{19,22,27,49}$ but sometimes we cannot exclude that there could be a real possibility of damage. As Welch points out, that's why radiologists have called them 'incidentalomas', from incidental as in 'minor or trivial', and 'oma' meaning growths or tumors. ${ }^{27}$ Therefore, the word incidentaloma implies uncertainty. In very few cases we know that screening of the tumor or disease reduces mortality or morbidity associated with it. Moynihan states that a diagnostic test is usually assessed according to how well it detects presence versus absence of a certain disease, rather than how well it detects clinically meaningful stages of diseases or abnormalities (where a disease label and associated intervention will do more harm than good). ${ }^{50}$

The vast majority of the malignant tumors incidentally found represent overdiagnosis because basically there are much more incidentalomas, than people dying from the respective cancers. ${ }^{26,27}$ We can see changes in the incidence for some cancers, where the rapidly rising in diagnosis (for example, thyroid cancer), ${ }^{25,51-54}$ is not followed by a decrease of death rates (they remain relatively stable), and this is a phenomenon suggestive of widespread overdiagnosis. ${ }^{49}$ Cancer overdiagnosis happens due to the detection of some malignant lesions that will never progress (or, in fact, regress) or will progress too slowly enough that the patient dies of other causes before the cancer becomes symptomatic. ${ }^{19}$ Less than $5 \%$ of lung nodules in smokers, and less than $1 \%$ of this incidentalomas could possible represent lethal cancers. ${ }^{27}$ So, 'a very small number of people will benefit from early detection of an incidental malignant tumor, while others will suffer the anxiety and adverse effects of further investigation and treatment of an "abnormality" that would never have harmed them'. ${ }^{49}$

\section{How to deal with incidentalomas}

The issue of what to do about incidentalomas is not simple. Doctors are not punished for overdiagnosis (neither for false-positive results), but they are punished for failing to diagnose. Guided in part by fears of lawsuits, and because of they were learning to be afraid to the uncertainty, clinicians tend to request additional tests which too often do not result in clinical clarity, diagnostic certainty, or patient satisfaction. The widespread belief in the unlimited capacity of medical science is one of a number of myths that reinforce the excess of medical activity. ${ }^{27,55-57}$ Medical technology is interventive, expansive, defines diseases and makes generalizations as well as strongly influences the concept of disease, and hence medical actions by defining what is diagnosed and what is treated. As it can generate reproducible results, technology has contributed to making medicine more scientific, and has made medical knowledge independent from the subjective experience of the patient. 
However, despite remarkable technologic advancement, the practice of medicine continues to involve uncertainty that along with faith in technology - as well as other factors - have contributed to increase the use of technology and technological development. ${ }^{58}$ Improvement in image quality combined with visualization as a cultural preference have contributed to a belief that imaging is a superior diagnostic method for acquiring knowledge about the body. ${ }^{59}$ Dealing with these findings inevitably consumes time and efforts, creates substantial anxiety for patients and doctors, and distracts them from their primary concerns. ${ }^{24}$ The additional medical care, including treatments, which in some cases may pose an additional risk to the patient triggered by an incidental finding, has been called the 'cascade effect'. ${ }^{60} \mathrm{~A}$ way to avoid incidental findings is to make an adequate selection of diagnostic or screening tests. The best approach is not to start the cascade, whenever we can.

Once the incidentaloma has been discovered, a way to deal with it is defining rational approaches to the problem. We can ask "What is the responsible use of information that nobody asked for?" ${ }^{11}$ Practitioners must use expensive resources responsibly, apply evidence rigorously, and validate the benefits of new technologies. ${ }^{18,55}$ Some reviews or consensus had been redacted for addressing incidental findings, ${ }^{24,47,61-65}$ but many of them implies to engage the patient in routine follow-ups with risks and costs for the health system and the patient.

In this regard, the EEUU Presidential Commission on Bioethics has developed a set of recommendations on this issue with four ethical principles applicable to the ethical assessment of incidental findings: (1) respect for persons (right to self-determination); (2) beneficence (and involves non-maleficence principle); (3) justice and fairness; and (4) intellectual freedom and responsibility (protects intellectual exploration that furthers scientific progress, but requiring that practitioners take responsibility for their actions). ${ }^{17}$ Recommendations of guidelines panels composed of generalists tend to be more conservative than those elaborated by experts, in part because they are chosen for their skills in critical appraisal and because they have little to gain from the recommendations. ${ }^{66}$

Patients' preferences should be taken into account, but they may have unrealistic expectations about the benefits of test results and are not typically aware that disclosure of results may actually be harmful. In many circumstances, a lot of patients will choose a test for low-probability conditions despite attendant costs, anxiety, and physical risks (e.g. prostate specific antigen ${ }^{67}$ or mammography in young women). ${ }^{68}$ Their decisions may depend not only on the likelihood of a particular event but also the perceived severity and significance of the consequences. ${ }^{18,24}$

Physicians ideally collaborate with patients to achieve decisions that are well informed and consonant with patients' values and preferences (shared decision making). It implies that clinicians and patients share the best available evidence, and clinicians have to discuss risk with patients in a straightforward and transparent manner, unless patients specify that they do not want the information..$^{24,69}$

There are now evidence-based decision support tools for clinicians and decision aids for patients; however, the knowledge about benefits, risks, and scientific uncertainty is not enough. In real life, decisions are strongly influenced by emotions such as beliefs and trust, fears, vulnerability, long-standing routines, personal experiences, messages conveyed by advertising and media, and the advice, testimonials, and transmitted knowledge imparted by trusted sources. People need hope, safety and a sense of control of their lives. If they are widely convinced that a screening test or drug is beneficial, confronting these beliefs can, if anything, engender suspicions about one's veracity and motives. There is still a universe dominated by the idea of unpolluted prevention (fostered by mass media, health insurance systems, pharmacy and health technology industries, and many doctors' messages).

Unrealistic expectations therefore persist, not only due to misinformation. False expectations fuel market demand for products, industries, and health delivery systems and can be fomented by misleading advertising. Confronting these expectations can not only dash hopes but potentially threaten profits, shareholders, clinical practices, industries, legislation, and political careers. In order to avoid the harm of excessive prevention activity, the doctor should consider the fears and expectations of the patient, but as we see, the landscape is not an easy one. ${ }^{65,70}$

When evidence is clear regarding benefit versus harm (i.e. screening might reduce cancer mortality by that specific tumor), we can agree with patients whether or not incidentaloma will be disclosed when obtaining their consent for testing. However, when evidence is not clear, we will need to describe potential benefits and risks to patients and helping them make decisions that incorporate their own values and preferences. ${ }^{18,27}$ In that case, one could tell the patient about the incidentaloma, and engaging the patient in shared decision making (but then we could scare the patient about the risk of a possible cancer). Radiologists could consider ignoring incidentalomas in this category, ${ }^{27}$ but it is not a general consensus ('Despite the potential harms, radiologists should report incidental imaging findings and frame reports to help patients make optimal decisions about them'). ${ }^{24}$ 
Finally, when it is known that screening does not reduce mortality, doctors can avoid call it abnormality, and so protect their patient from overdiagnosis and overtreatment. ${ }^{27} \mathrm{~A}$ working group at a meeting convened by the National Cancer Institute to mitigate overdiagnosis, proposed that the use of the term "cancer" should be reserved for describing lesions with a reasonable likelihood of lethal progression if left untreated. They said that premalignant conditions (e.g. ductal carcinoma in situ or high-grade prostatic intraepithelial neoplasia) should not be labeled as cancer, carcinoma or neoplasia, but rename such cancers as IDLE (indolent lesions of epithelial origin) conditions. ${ }^{20}$ Changing the words probably would help to change the symbolic meaning of them, and facilitate the paradigm shift towards a less intrusive medicine.

\section{Conclusion}

A disease can be now diagnosed based on laboratory tests in the absence of clinical signs and symptoms, and it is not always a good thing. The unintended findings of diagnostic procedures have changed diseases definition and incidence (have created a new kind of disease, the incidentaloma), and have generated substantial amounts of overdiagnosis and overtreatment, because in very few cases they represent a disease that deserves to be considered and treated. In a world dominated by images, by the search for certainty and reinsurance, by the medicalization of everyday life, resisting the onslaught of medical technology is not easy. Additionally, incidental findings usually cause fear, anxiety, worry and create the need for a follow-up to ensure the persons to feel healthy.

Hence, even when incidentalomas are non-significant they will have broken the sense of health. In some sense, incidentaloma has to do with the impossibility of not to do. Many times, because of fears and beliefs of patients and doctors, as well as in many others situations, the incidentaloma is one possible consequence of not saying 'don't do it' while adverse effects could be the consequence of a good care process. A popular phrase says 'the road to hell is paved with good intentions', advances in medical technology have brought countless positive changes, but also have unintended consequences, sometimes negative. It is essential to minimize these undesirable consequences, and perhaps it is time to change the paradigms.

\section{References}

1. Choyke PL, ACR Committee on Appropriateness Criteria. ACR Appropriateness Criteria on incidentally discovered adrenal mass. J Am Coll Radiol. 2006;3(7):498-504. http://dx.doi.org/10.1016/j.jacr.2006.02.031. PMid:17412112.

2. BabelNet. Dictionnary and semantic network [Internet]. Rome: Sapienza University of Rome. [cited 2014 Nov 14]. Available from: http://babelnet.org/synset?word=incidentaloma\&lang=EN\&details=1\&orig=incidentaloma.

3. Mirilas P, Skandalakis JE. Benign anatomical mistakes: incidentaloma. Am Surg. 2002;68(11):1026-1028. PMid:12455801.

4. Geelhoed GW, Druy EM. Management of the adrenal "incidentaloma”. Surgery. 1982;92(5):866-874. PMid:7135206.

5. O'Leary TJ, Ooi TC. The adrenal incidentaloma. Can J Surg. 1986;29(1):6-8. PMid:3940589.

6. Waldner H, Wilker D, Eibl-Eibesfeldt B. Therapeutic procedure in "incidentaloma" of the adrenal glands. Chirurg. 1986;57(9):557-559. PMid:3780354.

7. Ooi TC. Adrenal incidentalomas: incidental in detection, not significance. CMAJ. 1997;157(7):903-904. PMid:9327799.

8. Molitch ME, Russell EJ. The pituitary “incidentaloma”. Ann Intern Med. 1990;112(12):925-931. http://dx.doi.org/10.7326/0003-4819-112-12-925. PMid:2187392.

9. Cohen MS, Arslan N, Dehdashti F, Doherty GM, Lairmore TC, Brunt LM, et al. Risk of malignancy in thyroid incidentalomas identified by fluorodeoxyglucose-positron emission tomography. Surgery. 2001;130(6):941-946. http://dx.doi.org/10.1067/msy.2001.118265. PMid:11742321.

10. Pesenti M, Frasoldati A, Azzarito C, Valcavi R. Parathyroid incidentaloma discovered during thyroid ultrasound imaging. J Endocrinol Invest. 1999;22(10):796-799. http://dx.doi.org/10.1007/BF03343646. PMid:10614530.

11. Reincke M, Allolio B, Saeger W, Menzel J, Winkelmann W. The 'incidentaloma' of the pituitary gland. Is neurosurgery required? JAMA. 1990;263(20):2772-2776. PMid:2332920. http://dx.doi.org/10.1001/jama.1990.03440200076026.

12. Bramnert M. Hypophyseal incidentaloma is a common finding requiring investigation. The question is: surgery, medication or wait-and-see? Lakartidningen. 1998;95(30-31):3300-3303. PMid:9715067.

13. Little JM, Kenny J, Hollands MJ. Hepatic incidentaloma: a modern problem. World J Surg. 1990;14(4):448-451. http://dx.doi.org/10.1007/BF01658665. PMid:2166378.

14. Iannicelli P, Rosa A. Diagnostic imaging of kidney carcinomas. Our experience and review of the literature. Minerva Urol Nefrol. 1992;44(3):177-183. PMid:1492268. 
15. Al-Shahi Salman R, Whiteley WN, Warlow C. Screening using whole-body magnetic resonance imaging scanning: who wants an incidentaloma? J Med Screen. 2007; 14(1):2-4. http://dx.doi.org/10.1258/096914107780154530. PMid:17362563.

16. Wolf SM, Lawrenz FP, Nelson CA, Kahn JP, Cho MK, Clayton EW, et al. Managing incidental findings in human subjects research: analysis and recommendations. J Law Med Ethics. 2008; 36(2):219-248. http://dx.doi.org/10.1111/j.1748-720X.2008.00266.x. PMid:18547191.

17. Presidential Commission for the Study of Bioethical Issues. Anticipate and communicate: ethical management of incidental and secondary findings in the clinical, research, and direct-to-consumer contexts [Internet]. Washington: Presidential Commission for the Study of Bioethical Issue; 2013 [cited 2014 Nov 11]. Available from: http://bioethics.gov/sites/default/files/FINALAnticipateCommunicate_PCSBI_0.pdf.

18. Ells C, Thombs BD. The ethics of how to manage incidental findings. CMAJ. 2014;186(9):655-656. http://dx.doi.org/10.1503/cmaj.140136. PMid:24688013.

19. Welch HG, Black WC. Overdiagnosis in cancer. J Natl Cancer Inst. 2010;102(9):605-613. http://dx.doi.org/10.1093/jnci/djq099. PMid:20413742.

20. Esserman LJ, Thompson IM Jr, Reid B. Overdiagnosis and overtreatment in cancer: an opportunity for improvement. JAMA. 2013;310(8):797-798. http://dx.doi.org/10.1001/jama.2013.108415. PMid:23896967.

21. Esserman LJ, Thompson IM, Reid B, Nelson P, Ransohoff DF, Welch HG, et al. Addressing overdiagnosis and overtreatment in cancer: a prescription for change. Lancet Oncol. 2014;15(6):e234-e242. http://dx.doi.org/10.1016/S1470-2045(13)70598-9. PMid:24807866.

22. Moynihan R, Doust J, Henry D. Preventing overdiagnosis: how to stop harming the healthy. BMJ. 2012; 344:e3502. http://dx.doi.org/10.1136/bmj.e3502. PMid:22645185.

23. Hall WB, Truitt SG, Scheunemann LP, Shah SA, Rivera MP, Parker LA, et al. The prevalence of clinically relevant incidental findings on chest computed tomographic angiograms ordered to diagnose pulmonary embolism. Arch Intern Med. 2009;169(21):1961-1965. http://dx.doi.org/10.1001/archinternmed.2009.360. PMid:19933956.

24. Brown SD. Professional norms regarding how radiologists handle incidental findings. J Am Coll Radiol. 2013;10(4):253-257. http://dx.doi.org/10.1016/j.jacr.2012.10.003. PMid:23545084.

25. Davies L, Welch HG. Increasing incidence of thyroid cancer in the United States, 1973-2002. JAMA. 2006;295(18):2164-2167. http://dx.doi.org/10.1001/jama.295.18.2164. PMid:16684987.

26. Black WC, Haggstrom DA, Welch HG. All-cause mortality in randomized trials of cancer screening. J Natl Cancer Inst. 2002;94(3):167-173. http://dx.doi.org/10.1093/jnci/94.3.167. PMid:11830606.

27. Welch HG, Schwartz L, Woloshin S. Overdiagnosed: making people sick in the pursuit of health. Boston: Beacon Press; 2011.

28. Ginnerup Pedersen B, Rosenkilde M, Christiansen TE, Laurberg S. Extracolonic findings at computed tomography colonography are a challenge. Gut. 2003;52(12):1744-1747. http://dx.doi.org/10.1136/gut.52.12.1744. PMid:14633954.

29. Xiong T, Richardson M, Woodroffe R, Halligan S, Morton D, Lilford RJ. Incidental lesions found on CT colonography: their nature and frequency. Br J Radiol. 2005;78(925):22-29. http://dx.doi.org/10.1259/bjr/67998962. PMid:15673525.

30. Yee J, Kumar NN, Godara S, Casamina JA, Hom R, Galdino G, et al. Extracolonic abnormalities discovered incidentally at CT colonography in a male population. Radiology. 2005;236(2):519-526. http://dx.doi.org/10.1148/radiol.2362040166. PMid:16040909.

31. Fletcher RH, Pignone M. Extracolonic findings with computed tomographic colonography: asset or liability? Arch Intern Med. 2008;168(7):685-686. http://dx.doi.org/10.1001/archinte.168.7.685. PMid:18413549.

32. Pickhardt PJ, Kim DH, Meiners RJ, Wyatt KS, Hanson ME, Barlow DS, et al. Colorectal and extracolonic cancers detected at screening CT colonography in 10,286 asymptomatic adults. Radiology. 2010;255(1):83-88. http://dx.doi.org/10.1148/radiol.09090939. PMid:20308446.

33. Furtado CD, Aguirre DA, Sirlin CB, Dang D, Stamato SK, Lee P, et al. Whole-body CT screening: spectrum of findings and recommendations in 1192 patients. Radiology. 2005;237(2):385-394. http://dx.doi.org/10.1148/radiol.2372041741. PMid:16170016.

34. Lumbreras B, Donat L, Hernández-Aguado I. Incidental findings in imaging diagnostic tests: a systematic review. Br J Radiol. 2010;83(988):276-289. http://dx.doi.org/10.1259/bjr/98067945. PMid:20335439.

35. Morris Z, Whiteley WN, Longstreth WT Jr, Weber F, Lee YC, Tsushima Y, et al. Incidental findings on brain magnetic resonance imaging: systematic review and meta-analysis. BMJ. 2009; 339:b3016. http://dx.doi.org/10.1136/bmj.b3016. PMid:19687093.

36. Juvela S, Poussa K, Lehto H, Porras M. Natural history of unruptured intracranial aneurysms: a long-term follow-up study. Stroke. 2013;44(9):24142421. http://dx.doi.org/10.1161/STROKEAHA.113.001838. PMid:23868274.

37. Greving JP, Wermer MJ, Brown RD Jr, Morita A, Juvela S, Yonekura M, et al. Development of the PHASES score for prediction of risk of rupture of intracranial aneurysms: a pooled analysis of six prospective cohort studies. Lancet Neurol. 2014;13(1):59-66. http://dx.doi.org/10.1016/S1474-4422(13)70263-1. PMid:24290159.

38. Naggara ON, Lecler A, Oppenheim C, Meder JF, Raymond J. Endovascular treatment of intracranial unruptured aneurysms: a systematic review of the literature on safety with emphasis on subgroup analyses. Radiology. 2012;263(3):828-835. http://dx.doi.org/10.1148/radiol.12112114. PMid:22623696.

39. Al-Shahi Salman R, White PM, Counsell CE, du Plessis J, van Beijnum J, Josephson CB, et al. Outcome after conservative management or intervention for unruptured brain arteriovenous malformations. JAMA. 2014;311(16):1661-1669.

http://dx.doi.org/10.1001/jama.2014.3200. PMid:24756516. 
40. Bederson JB, Awad IA, Wiebers DO, Piepgras D, Haley EC Jr, Brott T, et al. Recommendations for the management of patients with unruptured intracranial aneurysms: A statement for healthcare professionals from the Stroke Council of the American Heart Association. Circulation. 2000;102(18):2300-2308. http://dx.doi.org/10.1161/01.CIR.102.18.2300. PMid:11056108.

41. Slanetz PJ, Hahn PF, Hall DA, Mueller PR. The frequency and significance of adnexal lesions incidentally revealed by CT. AJR Am J Roentgenol. 1997;168(3):647-650. http://dx.doi.org/10.2214/ajr.168.3.9057508. PMid:9057508.

42. Gore RM, Newmark GM, Thakrar KH, Mehta UK, Berlin JW. Pelvic incidentalomas. Cancer Imaging. $2010 ; 10$ Spec no A(1A):S15-S26. http://dx.doi.org/10.1102/1470-7330.2010.9021. PMid:20880789.

43. Solnik MJ, Alexander C. Ovarian incidentaloma. Best Pract Res Clin Endocrinol Metab. 2012;26(1):105-116. http://dx.doi.org/10.1016/j.beem.2011.07.002. PMid:22305456.

44. Buys SS, Partridge E, Black A, Johnson CC, Lamerato L, Isaacs C, et al. Effect of screening on ovarian cancer mortality: the Prostate, Lung, Colorectal and Ovarian (PLCO) Cancer Screening Randomized Controlled Trial. JAMA. 2011;305(22):2295-2303. http://dx.doi.org/10.1001/jama.2011.766. PMid:21642681.

45. Kohane IS, Masys DR, Altman RB. The incidentalome: a threat to genomic medicine. JAMA. 2006;296(2):212-215. http://dx.doi.org/10.1001/ jama.296.2.212. PMid:16835427.

46. Christensen K, Kalia S, Green R. Incidental findings from genetic testing [cited 2014 Nov 13]. In: UpToDate [Internet]. Filadelfia (PA): WoltersKluwer Health; 2014. Available from: http://www.uptodate.com/es/home

47. Green RC, Berg JS, Grody WW, Kalia SS, Korf BR, Martin CL, et al. ACMG recommendations for reporting of incidental findings in clinical exome and genome sequencing. Genet Med. 2013;15(7):565-574. http://dx.doi.org/10.1038/gim.2013.73. PMid:23788249.

48. Solomon BD. Incidentalomas in genomics and radiology. N Engl J Med. 2014;370(11):988-990. http://dx.doi.org/10.1056/NEJMp1310471. PMid:24620864.

49. Moynihan R, Doust J, Henry D. Preventing overdiagnosis: how to stop harming the healthy. BMJ. 2012;344:e3502. http://dx.doi.org/10.1136/bmj.e3502. PMid:22645185.

50. Moynihan R, Henry D, Moons KG. Using evidence to combat overdiagnosis and overtreatment: evaluating treatments, tests, and disease definitions in the time of too much. PLoS Med. 2014;11(7):e1001655. http://dx.doi.org/10.1371/journal.pmed.1001655. PMid:24983872.

51. Brito JP, Morris JC, Montori VM. Thyroid cancer: zealous imaging has increased detection and treatment of low risk tumours. BMJ. 2013; 347:f4706. http://dx.doi.org/10.1136/bmj.f4706. PMid:23982465.

52. Morris LG, Sikora AG, Tosteson TD, Davies L. The increasing incidence of thyroid cancer: the influence of access to care. Thyroid. 2013;23(7):885891. http://dx.doi.org/10.1089/thy.2013.0045. PMid:23517343.

53. Guay B, Johnson-Obaseki S, McDonald JT, Connell C, Corsten M. Incidence of differentiated thyroid cancer by socioeconomic status and urban residence: Canada 1991-2006. Thyroid. 2014;24(3):552-555. http://dx.doi.org/10.1089/thy.2013.0308. PMid:24003960

54. Udelsman R, Zhang Y. The epidemic of thyroid cancer in the United States: the role of endocrinologists and ultrasounds. Thyroid. 2014;24(3):472479. http://dx.doi.org/10.1089/thy.2013.0257. PMid:23937391.

55. Stone JH. Incidentalomas--clinical correlation and translational science required. N Engl J Med. 2006;354(26):2748-2749. http://dx.doi.org/10.1056/NEJMp058264. PMid:16807411.

56. Heath I. Role of fear in overdiagnosis and overtreatment-an essay by lona Heath. BMJ. 2014; $349: 96123$. http://dx.doi.org/10.1136/bmj.g6123. PMid:25954986.

57. Hoffman JR, Kanzaria HK. Intolerance of error and culture of blame drive medical excess. BMJ. $2014 ; 349: 95702$. http://dx.doi.org/10.1136/bmj.g5702. PMid:25315302.

58. Hofmann B. Too much of a good thing is wonderful? A conceptual analysis of excessive examinations and diagnostic futility in diagnostic radiology. Med Health Care Philos. 2010;13(2):139-148. http://dx.doi.org/10.1007/s11019-010-9233-8. PMid:20151206.

59. Wagner J, Aron DC. Incidentalomas: a "disease" of modern imaging technology. Best Pract Res Clin Endocrinol Metab. 2012;26(1):3-8. http://dx.doi.org/10.1016/j.beem.2011.08.006. PMid:22305448.

60. Mold JW, Stein HFC. The cascade effect in the clinical care of patients. N Engl J Med. 1986;314(8):512-514. http://dx.doi.org/10.1056/NEJM198602203140809. PMid:3945278

61. Berland LL, Silverman SG, Gore RM, Mayo-Smith WW, Megibow AJ, Yee J, et al. Managing incidental findings on abdominal CT: white paper of the ACR incidental findings committee. J Am Coll Radiol. 2010;7(10):754-773. http://dx.doi.org/10.1016/j.jacr.2010.06.013. PMid:20889105.

62. Terzolo M, Stigliano A, Chiodini I, Loli P, Furlani L, Arnaldi G, et al. AME position statement on adrenal incidentaloma. Eur J Endocrinol. 2011;164(6):851-870. http://dx.doi.org/10.1530/EJE-10-1147. PMid:21471169.

63. Freda PU, Beckers AM, Katznelson L, Molitch ME, Montori VM, Post KD, et al. Pituitary incidentaloma: an endocrine society clinical practice guideline. J Clin Endocrinol Metab. 2011;96(4):894-904. http://dx.doi.org/10.1210/jc.2010-1048. PMid:21474686.

64. Patel MD, Ascher SM, Paspulati RM, Shanbhogue AK, Siegelman ES, Stein MW, et al. Managing incidental findings on abdominal and pelvic CT and MRI, part 1: white paper of the ACR Incidental Findings Committee II on adnexal findings. J Am Coll Radiol. 2013;10(9):675-681. http://dx.doi.org/10.1016/j.jacr.2013.05.023. PMid:24007607. 
65. Berland LL. Overview of white papers of the ACR incidental findings committee ii on adnexal, vascular, splenic, nodal, gallbladder, and biliary findings. J Am Coll Radiol. 2013;10(9):672-674. http://dx.doi.org/10.1016/j.jacr.2013.05.012. PMid:23816427.

66. Woolf SH. The price of false beliefs: unrealistic expectations as a contributor to the health care crisis. Ann Fam Med. 2012;10(6):491-494. http://dx.doi.org/10.1370/afm.1452. PMid:23149524.

67. U.S. Preventive Services Task Force (USPSTF). Prostate cancer: screening [Internet]. Rockville: USPSTF; 2012 [cited 2014 Nov 14]. Available from: http://www.uspreventiveservicestaskforce.org/Page/Topic/recommendation-summary/prostate-cancer-screening .

68. Yankaskas BC, Haneuse S, Kapp JM, Kerlikowske K, Geller B, Buist DS, et al. Performance of first mammography examination in women younger than 40 years. J Natl Cancer Inst. 2010;102(10):692-701. http://dx.doi.org/10.1093/jnci/djq090. PMid:20439838.

69. Elwyn G, Laitner S, Coulter A, Walker E, Watson P, Thomson R. Implementing shared decision making in the NHS. BMJ. 2010 ; 341 :c5146. http://dx.doi.org/10.1136/bmj.c5146. PMid:20947577.

70. Gérvas J, Heath I, Durán A, Gené J, Members of the Seminar of Primary Health Innovation 2008. Clinical prevention: patients' fear and the doctor's guilt. Eur J Gen Pract 2009;15(3):122-124. PMid:19883148. http://dx.doi.org/10.3109/13814780903242481. 